\title{
TRACEABILITY AND CERTIFICATION OF SEED POTATO BY BLOCKCHAIN TECHNOLOGY
}

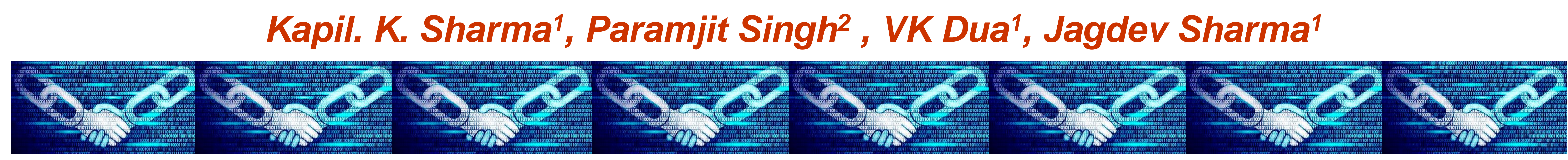

Introduction

The use of blockchain technology for the seed supply chain brings real change to seed management. It provides the ability to track the purity of the seed. The unique digital identity created for every batch of seeds provides a complete history of the seed supply chain providing transparency and visibility to the buyer.

Potato is designated as "Future Food" for food and nutritional security to the developing world by FAO in 2008 In Indian Agri-scenario potato's is the fourth most important food crop after Rice, wheat and maize. Potato, a vegetatively propagated crop, and its yield is affected by several factors. Among them, quality seed is one of the most important factors. 40 to 50 percent of the input cost goes for seed purchase. The average yield increase from 30 to 50 percent by the use of good quality seed as compared to farmers' seeds was reported by FAO in a document on potato in the Asia Pacific. (https://www.fao.org/3/i0200e/l0200E05.htm).

Punjab stands 6 th in total potato production of 2.87 million tonnes, recording the third-highest productivity $(28.70 \mathrm{t} / \mathrm{ha})$ from an area of 1.06 lakh ha in 2019-20(Horticulture Statistics Division, Department of Agri. \& Cooperation). Its unique agro-climate has enabled it to evolve as the major disease-free seed producer of the country, which meets $90 \%$ of the total disease-free potato requirement of the country (Status report Department of Horticulture, Punjab).

An evaluation of the prevalent seed systems in Punjab revealed that both the formal and informal seed systems were prevalent in the state. Based on an estimate the formal seed system contributes only $20 \%$ of the total seed production in India, used by growers whereas the other $80 \%$ is contributed by the informal system (Kadian et al., 2007).

Methodology

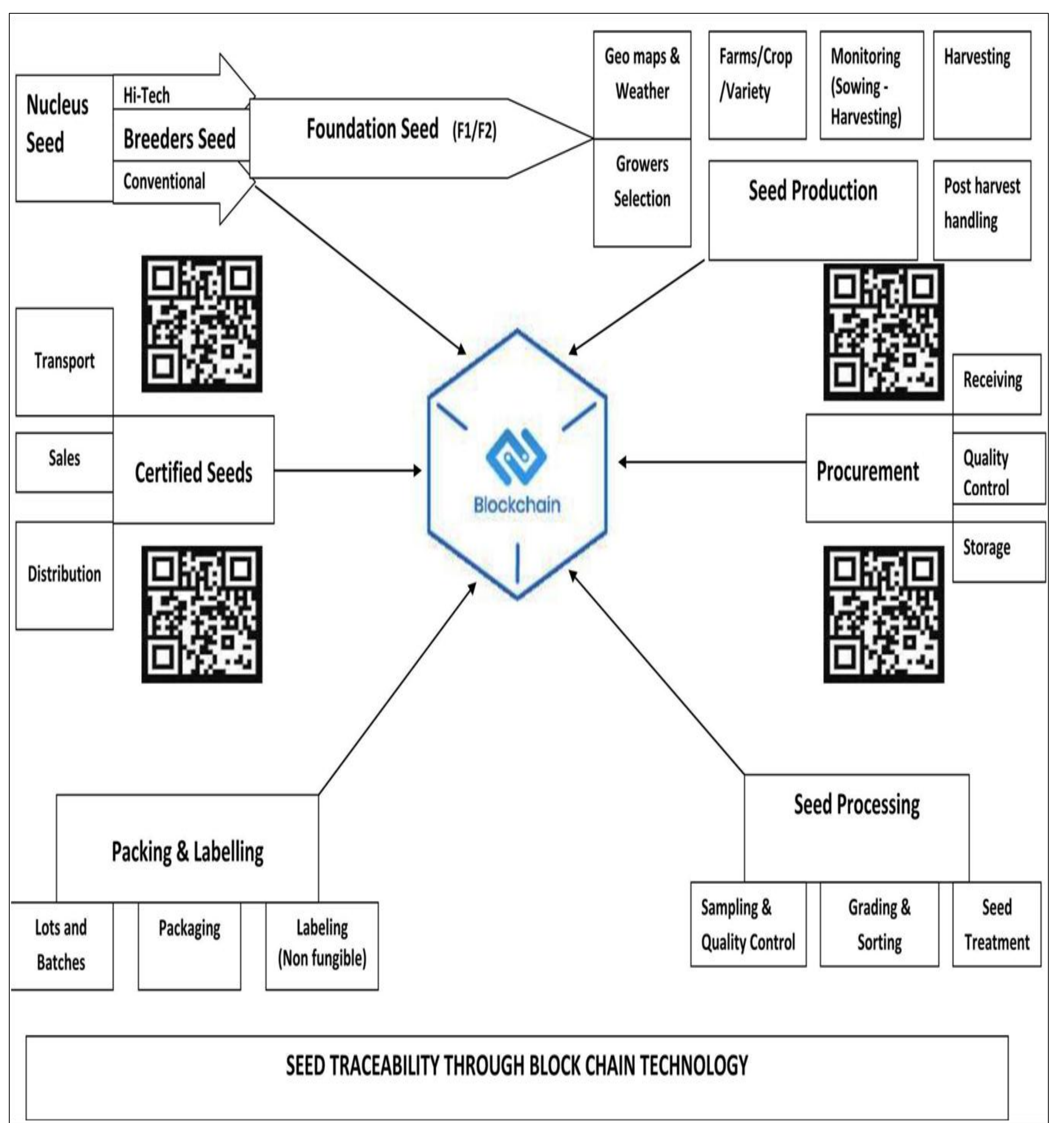

Results and discussion

Data of Seed Potato producing farmers/agencies and area under Seed Traceability programme in Punjab

\begin{tabular}{|c|c|c|c|c|c|}
\hline \multirow{2}{*}{ Crop Season } & $\begin{array}{c}\text { No. of } \\
\text { Farmers }\end{array}$ & \multicolumn{4}{|c|}{ Area under audit for tagging and certification in acres } \\
\cline { 4 - 6 } & $\begin{array}{c}\text { Agencies } \\
\text { participated }\end{array}$ & $\begin{array}{c}\text { Breeder } \\
\text { Seed }\end{array}$ & Foundation-1 & Foundation-2 & $\begin{array}{c}\text { Total Area } \\
\text { (Acres) }\end{array}$ \\
\cline { 4 - 6 } $2019-20$ & 23 & 97.09 & 359.95 & 1352.77 & 1809.81 \\
\hline $2020-21$ & 23 & 94.07 & 354.44 & 1051.12 & 1499.63 \\
\hline
\end{tabular}

Punjab has earned the status of "Seed Bowl of Potato" in the country. Seed potato is being supplied to other states from both formal and informal seed systems. The steady increase in manipulations on the quality of seed potato from Punjab has caused huge economic losses and eroded consumers' trust. It becomes a pressing issue for producers, researchers, governments, consumers, and other stakeholders working in Seed Potato production in Punjab. Tracking and authenticating the seed potato in the supply chain to understand provenance is critical with a view to identifying and addressing sources of contamination in the supply chain. One way of solving traceability issues and ensuring transparency is by using block chain technology and the Internet of things (loT) to collect and store data in chronological order to prevent manipulations afterward. Department of Agriculture and Welfare, Government of Punjab in the Year 2019 initiated the certification and traceability of seed potato to ensure optimum transparency. This task was entrusted to Punjab Agri Export Corporation (PAGREXCO) along with a Bangalore based company-Cropin Technology Solutions as the technology partner. Blockchain technology will be used to undertake certification and traceability of seed potato right from nucleus to seed level (harvest). In the crop season 2019-20 a group of 23 farmers/seed producing agencies come under the umbrella with 1809.80 acres of seed potato of different varieties registered for certification. In year 2020-21, area under certification was 1499.63 acres.

\section{Conclusion and Suggestions}

The blockchain use for the food and agriculture sector has proven to be the best-known way of assuring transparency and at the same time has become an essential tool to protect the investment in seed research and development, which is necessary to achieve a sustainable food and material supply for a growing population.

The potential of block chain technology for assuring traceability and authenticity for the quality of seed potato in the supply chain will prove a milestone in the future for seed Potato growers of Punjab. 